Portland State University

PDXScholar

1973

\title{
Some Aspects of the Water Economics of Townsend's Chipmunks
}

\author{
Ali Mokhtar Rahima \\ Portland State University
}

Follow this and additional works at: https://pdxscholar.library.pdx.edu/open_access_etds

Part of the Biology Commons

Let us know how access to this document benefits you.

\section{Recommended Citation}

Rahima, Ali Mokhtar, "Some Aspects of the Water Economics of Townsend's Chipmunks" (1973). Dissertations and Theses. Paper 1589.

https://doi.org/10.15760/etd.1588

This Thesis is brought to you for free and open access. It has been accepted for inclusion in Dissertations and Theses by an authorized administrator of PDXScholar. Please contact us if we can make this document more accessible: pdxscholar@pdx.edu. 
SOME ASPECTS OF THE WATER ECONOMICS OF

TOWNSEND'S CHIPMUNKS

by

ALI MOKHTAR RAHIMA

A thesis submitted in partial fulfillment of the requirements for the degree of

MASTER OF SCIENCE

in

BIOLOGY

Portland State University

1973 
TO THE OFFICE OF GRADUATE STUDIES AND RESEARCH:

The members of the Committee approve the thesis of Ali Mokhtar

Rahima presented $16 \mathrm{July} 1973$.

Richard Forbes, Chairman

Leonard Simpson

$-$

Earl Fisher, Jr.

David Clark

APPROVED :

$\longrightarrow$

Earl Fisher, Jr., Head, Department of Biology

David T. Clark, Dean of Graduate Studies 
ACKNOWLEDGEMENTS

I am grateful to Dr. Richard Forbes, my research supervisor and thesis advisor, for his patient guidance and help at every stage of this study. I also wish to convey my thanks and warmest appreciation to Dr. Leonard Simpson for his academic advice and to Dr. Earl Fisher, Dr. Simpson and Dr. Forbes for their service on my thesis committee. I am grateful to Paul Sherman for providing one of the animals $I$ used and to the Biology Department for providing the space and materials used for this study. Finally I wish to express my thanks and appreciation to the University of Libya, Faculty of Science, for providing me with this opportunity for study. 
ACKNOWLEDGEMENTS. .............................. Iv

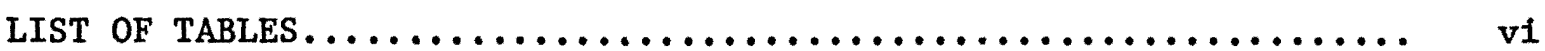

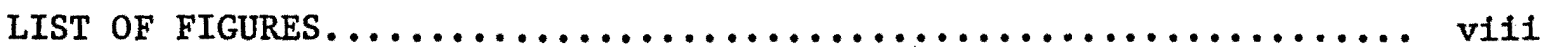

INTRODUCTION................................... 1

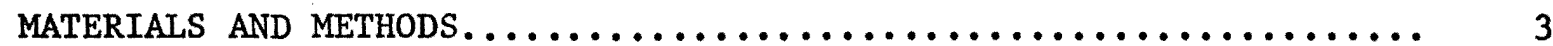

Capture of the Chipmunks....................... 3

Maintenance of the Animals....................... 3

Ad Libitum Water Consumption.................... 3

Water Deprivation............................ 4

Saline Water Consumption....................... 4

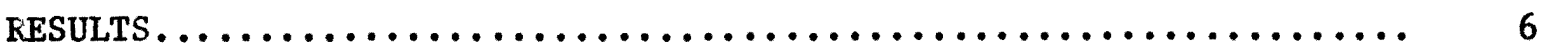

Ad Libitum Water Consumption..................... 6

Weight Loss During Water Deprivation................ 6

Salt Water Consumption......................... 19

DISCUSSION...................................... 25

Ad Libitum Water Consumption..................... 25

Responses to Water Deprivation................... 27

Saline Solution Consumption.................... 28

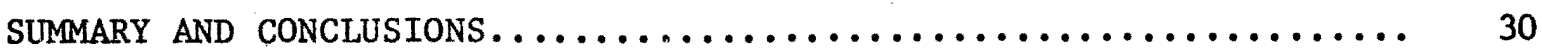

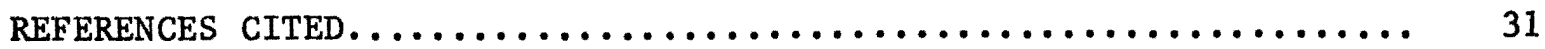


AN ABSTRACT OF THE THESIS OF Ali Mokhtar Rahima for the Master of

Science in Biology presented 16 July $19 ; 3$.

Title: Some Aspects of the Water Economics of Townsend's Chipmunks

APPROVED BY MEMBERS OF THE THESIS COMMITTEE:

Richard Forbes, Chairman

Leonard Simpson

Ear1 Fisher, Jr.

\section{Daviá Clark}

Water consumption, and weight loss in response to water deprivation and saline water consumption, were studied in the Eutamias townsendit townsendii from Portland, Multnomah County, Oregon. These chipmunks occupy moist Pacific Northwest forests. The results of these studies suggest that Townsend's chipmunks are dependent on sources of drinking water, at least for normal aboveground activity, that their tolerance for water deprivation is comparactvely low, and that they are unable to oitaln a net gain of water by drinking $0.2 \mathrm{M}$ sodium chloride solutions. Chipmunks cannot drink $0.4 \mathrm{M} \mathrm{NaCl}$ solution and survive for more than a few days. Metabolic water and preformed water in air dry food are not adequate to meet these animals' water needs. 
TABLE

PAGE

I Daily body weights and ad libitum water consumption

of $8 \mathrm{E}$. $\underline{\text {. }}$ townsendil during an 8 -day period......... 8

II Daily body weights and ad 1ibitum water consumption

of 8 E. t. townsendil during a 10-day period.......... 9

III Water consumption per gram of body weight per day of

8 E. ․․ townsendii during an 8-day period.......... 10

IV Water consumption per gram of body weight per day of

8 E. ․․ townsendii during a 10 -day period.......... 11

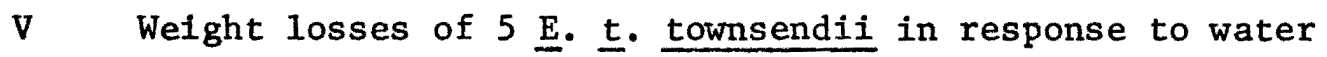

deprivation for a 5-day period (Experiment I)........ 12

VI Comparison of mean body weights of $5 \underline{E} . \underline{t}$. townsendii deprived

of drinking water and 3 control animals with ad libitum

access to water (Experiment I) $\ldots \ldots \ldots \ldots \ldots \ldots \ldots \ldots$

VII Weight losses of $5 \underline{E}$. $\underline{\text {. }}$ townsendii in response to water

deprivation for a 5-day period (Experiment II)....... 14

VIII Comparison of mean body weights of $5 \underline{E}$. $\underline{t}$. townsendii

deprived of drinking water and control animals with

ad Iibitum access to water (Experiment II)......... 16

IX Weight gains of 5 dehydrated $\underline{E}$. $\underline{\text { t. townsendii during } 5}$

days after ad libitum access to drinking water was

restored (Experiment I) $\ldots \ldots \ldots \ldots \ldots \ldots \ldots \ldots \ldots \ldots$ 
vii

TABLE

PAGE

X Fluid consumption and body weights of $5 \underline{E} . \underline{t}$. townsendii

given $0.1 \mathrm{M} \mathrm{NaCl}$ solution to drink.............. 20

XI Fluld consumption and body weights of $5 \underline{\mathrm{E}}$ t. t townsendil

given $0.2 \mathrm{M} \mathrm{NaC1}$ solution to drink.............. 21

XII F1uid consumption and body weights of $5 \underline{E} . \underline{t}$. townsendii

given $0.4 \mathrm{M}$ saline solution to drink............... 


\section{LIST OF FIGURES}

FIGURE

PAGE

1 Comparison of daily weight changes of 5 water-

deprived and 3 control E. $\underline{t}$. townsendii

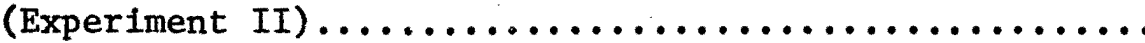

2 Mean daily body weights of $5 \underline{\mathrm{E}}$. $\underline{\text {. }}$ townsendii during

water deprivation and when ad libitum access to

water was restored (Experiment I) $\ldots \ldots \ldots \ldots \ldots \ldots \ldots 18$

3 Mean dally body weight changes of $5 \underline{E}$. $\underline{\text {. townsendii }}$

given NaCl. solutions to drink.................. 23

4 Mean daily consumption of $\mathrm{NaCl}$ solutions by 5

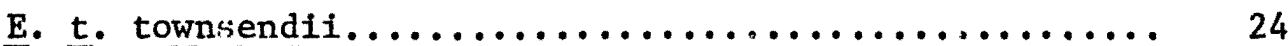




\section{INTRODUCTION}

Townsend's chipmunk, Eutamias townsendii townsendil was described by Bachman in 1839 from specimens collected around the lower mouth of the Willamette River about 25 miles below Portland, Multnomah County, Oregon. Members of this subspecies live in the humid transition life zone. They are found from the Cascade Mountains westward to the Pacific coast, and from southern British Columbia south to Myrtle Point, Oregon (Bailey 1936).

Although many aspects of the natural history of these and other chipmunks have been studied, the literature contains relatively few references to chipmunk physiology in general, and to water balance in particular. Jameson and Mead (1964) studied seasonal changes in body fat and water in Citellus lateralis, Eutamias speciosus and $\underline{E}$. amoenus. Forbes (1967) studied water economics of eastern and least chipmunks (Tamias striatus and Eutamias minimus) in northern Minnesota. Wunder (1970) investigated the effect of water restriction on Merriam's chipmunks (Eutamias merriami), a hot-desert species. Heller (1970) studied some aspects of water balance in E. alpinus, E. speciosus, E. minimus and E. amoenus in connection with his investigation of competition between . these species.

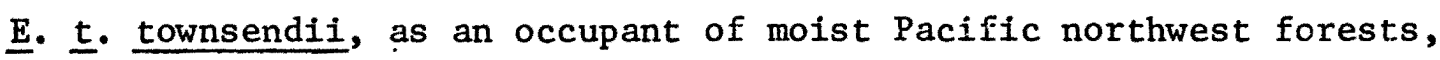
might be expected to differ in its water balance from the aforementioned species. It was the object of this study to determine, for purposes of comparison with other species and for a better understanding of its own natural history, the ad libitum water consumption, weight changes during 
dehydration and rehydration, and weight changes in response to drinking sallne water of E. t. townsendii. 
MATERIALS AND METHODS

\section{Capture of the Chipmunks}

Nine of the ten chipmunks used in this study were live-trapped, using $5 \times 5 \times 16$ inch National Live Traps, between late January and late March of 1973. Honey Almond Crunch candy was used as bait. One chipmunk, captured by Paul Sherman in the summer of 1972 and confined since then in an $8 \times 8 \times 6$ foot outdoor cage, was also used in this study. All the animals were trapped in wooded areas of western Portland, Multnomah County, Oregon.

Maintenance of the Animals

Each animal was kept in a metal cage $9 \times 9 \frac{1}{2} \times 6$ inches deep in an animal room of Science Building $I$ at Portland State University. The room was darkened (venetian blinds drawn) except when the animals were being weighed and examined once daily. The room was kept at a temperature of about $21^{\circ} \mathrm{C}$.

The animals were given air-dry Purina Lab Chow ad libitum as food. The guaranteed nutritional analysis of Purina Lab Chow is: crude protein, not less than $23.0 \%$; crude fat, not less than $45 \%$; crude fiber, not more than $6.0 \%$; and ash, not more than $9.0 \%$.

All cages were provided with wood shavings as 11tter. Access to water was controlled according to work in progress.

\section{Ad Libitum Water Consumption}

Tap water was provided in a $100 \mathrm{cc}$ graduated drinking tube to each animal. A control tube hung on the cage rack permitted assessment of evaporative water loss from the tubes. 
The change in water level in each tube was recorded daily for eight days, and again for ten days. The animals were weighed once a day to the nearest $0.1 \mathrm{~g}$ on an Ohaus triple beam balance of $610 \mathrm{~g}$ caparity.

Each animal's water consumption per gram of body weight per day was calculated by dividing mean daily water consumption by the mean daily weight of the animal during the experimental period.

\section{Water Deprivation}

Five animals were deprived of drinking water and weighed daily, in order to determine rates of weight loss during five days of water deprivation. Three control animals were treated in the same manner except that drinking water was available to them. In order to determine the rate of gain in body weight during rehydration, the five experimental animals were given ad libitum access to tap water following the five days of dehydration. The weights of both experimental and control animals were recorded daily for 5 days.

The experiment was repeated when the experimental animals regained their pre-experimental weights.

\section{Saline Water Consumption}

In this study, five animals, caged and fed as usual, were given various concentrations of saline solution to drink. The saline solution was made of reagent sodium chloride and distilled water. Five experimental animals were given $0.1 \mathrm{M} \mathrm{NaC1}$ solution for five days, then $0.2 \mathrm{M}$ NaCl solutions for five more days, then $0.4 \mathrm{M}$ saline solution for two more days, after which the experiment was terminated. 
Three control animals were given tap water to drink. All animals were weighed once a day, and the amount of saline solution each animal drank was recorded daily.

All statistical computations were carried out according to the formulae of Simpson et a]. (1960). 


\section{RESULTS}

\section{Ad Libitum Water Consumption}

Forbes (1967) found chipmunks to be difficult subjects for experiments such as those here described. My chipmunks also were difficult to remove from their cages for weighing. Some individuals shook water out of their drinking tubes; others packed 1itter into the tubes. Two animals consistently spilled water from their drinking tubes. The data from work with these animals is not included in the results. Data on water consumption of the other eight chipmunks are summarized in Tables I - IV. As the data and statistical computations reveal, individual variation in ad Iibitum water consumption was great, both in the first (eight-day) and second (ten-day) periods of observation. It is possible that some of the high values for water consumption include small amounts of water that the animals spilled and which evaporated leaving no evidence of spillage. Thus, whether the animals actually drank as much as the highest values shown in the tables is uncertain.

\section{Weight Loss During Water Deprivation}

Weight losses of experimental animals in response to drinking water deprivation, and of control animals, are shown in Tables V-VIII. Weight gains when ad libitum access to drinking water was restored are shown in Table IX. Mean welght losses and gains of the experimental animals in Experiment II are shown in Figure 2.

The body weights of control animals varied only a few grams from pre-experimental weights. Experimental animals, in contrast, showed rapid weight losses during the two periods of water deprivation. This 
comparison is shown in Figure 1. However, the loss of weight by the experimental chipmunks cannot be attributed to water deprivation alone. I found that water-deprived auimals voluntarily cessed eating or greatly reduced their food intake. Thus, voluntary fasting, along with water deprivation, accounts for the weight losses sustained by the experimental animals.

There were some noticeable changes in the activity of water-deprived animals, compared to the controls. In the second day of dehydration, one experimental individual, 非, showed a slight decrease in activity, while the rest of the animals seemed to be normally active. By the third day, \#1 became even more listless. In the fourth day, one of the animals, \#5, became exceedingly active and more difficult than usual to catch for weighing, but 1 became even more listless. In day 5 , 非 1 was moving only with great difficulty. Two other experimental animals, 12 and $\# 5$ showed a slight decrease from their normal activity, while the remaining two experimental animals, and all control animals remained normally active. Animals $\# 1$ and $\# 2$, which 1 ost $40 \%$ and $38 \%$ of their body weight in Experiment 2, died immediately after the experimental period. 
TABLE I

DAILY BODY WEIGHTS AND AD LIBITUM WATER CONSUMPTION

OF $8 \underline{E} . \underline{T}$. TOWNSENDII DURING AN 8-DAY PERIOD

\begin{tabular}{|c|c|c|c|}
\hline $\begin{array}{c}\text { Animal } \\
\text { No. }\end{array}$ & $\begin{array}{l}\text { Weight }(g) \\
\bar{x} / R^{*}\end{array}$ & $\begin{array}{c}\mathrm{H}_{2} \mathrm{O} \text { Consumed } \\
\text { per day }(\mathrm{cc}) \\
\overline{\mathrm{x}} / \mathrm{R}^{*}\end{array}$ & $\begin{array}{c}\mathrm{H}_{2} \mathrm{O} \text { Consumed } \\
(\mathrm{cc}) \text { per } \mathrm{g} \\
\bar{x} / \mathrm{R}^{*}\end{array}$ \\
\hline 1 & $\frac{80.2}{80.9-83.1}$ & $\frac{13.5}{8.0-22.0}$ & $\frac{0.16}{0.09-0.27}$ \\
\hline 2 & $\frac{89.6}{85.9-93.8}$ & $\frac{16.3}{8.0-25.0}$ & $\frac{0.17}{0.09-0.27}$ \\
\hline 3 & $\frac{100.7}{98.7-102.4}$ & $\frac{18.5}{15.0-36.0}$ & $\frac{0.17}{0.14-0.35}$ \\
\hline & $\gamma$ & & \\
\hline 4 & $\frac{90.8}{85.6-92.6}$ & $\frac{13.1}{12.0-14.0}$ & $\frac{0.14}{0.13-0.15}$ \\
\hline 5 & $\frac{86.0}{83.9-94.7}$ & $\frac{7.2}{3.0-10.0}$ & $\frac{0.08}{0.03-0.11}$ \\
\hline 6 & $\frac{96.4}{92.1-100.2}$ & $\frac{13.4}{4.0-21.0}$ & $\frac{0.17}{0.04-0.21}$ \\
\hline 7 & $\frac{95.8}{92.6-97.7}$ & $\frac{12.4}{9.0-15.0}$ & $\frac{0.13}{0.09-0.16}$ \\
\hline 8 & $\frac{96.8}{91.7-102.5}$ & $\frac{20.0}{15.0-25.0}$ & $\frac{0.20}{0.16-0.25}$ \\
\hline
\end{tabular}

* $\overline{\mathbf{x}}=$ arithmetic mean; $\mathrm{R}=$ range 
TABIE II

DAILY BODY WEIGHTS AND AD LIBITUM WATER CONSUMPTION

OF 8 E. T. TOWNSENDII DURING A 10-DAY PERIOD

\begin{tabular}{|c|c|c|c|}
\hline $\begin{array}{c}\text { Animal } \\
\text { No. }\end{array}$ & $\begin{array}{l}\text { Weight }(g) \\
\bar{x} / R^{*}\end{array}$ & $\begin{array}{l}\mathrm{H}_{2} \mathrm{O} \text { Consumed } \\
\text { per day }(\mathrm{cc}) \\
\overline{\mathrm{x} / \mathrm{R}^{*}}\end{array}$ & $\begin{array}{l}\mathrm{H}_{2} \mathrm{O} \text { Consumed } \\
(\mathrm{cc}) \text { per } 8 \\
\bar{x} / \mathrm{R}^{*}\end{array}$ \\
\hline 1 & $\frac{76.4}{74.1-86.5}$ & $\frac{32.6}{27.0-35.0}$ & $\frac{0.38}{0.35-0.47}$ \\
\hline 2 & $\frac{91.0}{85.0-97.4}$ & $\frac{20.4}{8.0-29.0}$ & $\frac{0.21}{0.09-0.29}$ \\
\hline 3 & $\frac{98.3}{93.1-105.6}$ & $\frac{18.8}{15.0-26.0}$ & $\frac{0.19}{0.15-0.24}$ \\
\hline 4 & $\frac{88.5}{85.7-95.5}$ & $\frac{22.8}{15.0-29.0}$ & $\frac{0.24}{0.16-0.31}$ \\
\hline 5 & $\frac{82.0}{76.8-87.6}$ & $\frac{10.2}{8.0-13.0}$ & $\frac{0.12}{0.09-0.16}$ \\
\hline 6 & $\frac{100.0}{96.9-103.4}$ & $\frac{20.8}{8.0-30.0}$ & $\frac{0.20}{0.08-0.29}$ \\
\hline 7 & $\frac{95.3}{92.6-100.1}$ & $\frac{25.3}{18.0-43.0}$ & $\frac{0.26}{0.19-0.46}$ \\
\hline 8 & $\frac{104.6}{101.5-106.4}$ & $\frac{22.8}{19.0-29.0}$ & $\frac{0.21}{0.18-0.27}$ \\
\hline
\end{tabular}

* $\quad \overline{\mathrm{x}}=$ arithmetic mean; $\mathrm{R}=$ range 
TABLE III

WATER CONSUMPTION PER GRAM OF BODY WEIGHT PER DAY

OF 8 E. T. TOWNSENDII DURING AN 8-DAY PERIOD

$$
\bar{x}-*
$$

Welght $(g)$

ce $\mathrm{H}_{2} \mathrm{O} / \mathrm{g} /$ day

0.153
$0.08-0.20$

0.036

V*

$R_{\mathbf{x}} *$

$80.2-100.7$

6.7

7.27

92.0

0.036

0.0134

2.34

S*

$\mathrm{S} \overline{\mathbf{x}}_{\overline{\mathbf{x}}}{ }^{*}$

2.34

0.0134
24.4

* $\quad \mathrm{X}_{\mathrm{X}}=$ mean of arithmetic means

$$
\begin{aligned}
& R_{\bar{X}}=\text { range of mean } \\
& S=\text { standard deviation of mean of means } \\
& S_{\bar{x}_{\bar{X}}}=\text { standard error of mean of means } \\
& V=\text { coefficient of variation }
\end{aligned}
$$


TABLE IV

WATER CONSUMPTION PER GRAM OF BODY WEIGHT PER DAY

OF 8 E. T. TOWNSENDII DURING A 10-DAY PERIOD

$$
\overline{\mathrm{x}}-*
$$

92.0

$\mathrm{R}-*$

Weight $(g)$

cc $\mathrm{H}_{2} \mathrm{O} / \mathrm{g} /$ day

0.204

$0.19-0.24$

$76.4-104.6$

9.486

3.486

10.3

$\mathrm{S}_{\overline{\mathrm{x}}_{\overline{\mathbf{X}}}} \mathrm{V}^{*}$


TABLE V

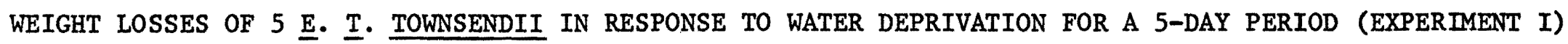
As compared to weight changes of 3 control animals (7,8, and 9)

Upper figure is body weight; lower figure is per cent of pre-experimental weight

\begin{tabular}{|c|c|c|c|c|c|c|}
\hline $\begin{array}{l}\text { Animal } \\
\text { No. }\end{array}$ & $\begin{array}{c}\text { Pre-experiment } \\
\text { Weight }\end{array}$ & Day 1 & Day 2 & Day 3 & Day 4 & Day 5 \\
\hline 1 & 80.0 & $\frac{68.5 \mathrm{~g}}{87 \%}$ & $\frac{63.3 \mathrm{~g}}{80 \%}$ & $\frac{57.5 \mathrm{~g}}{74 \%}$ & $\frac{52.1 \mathrm{~g}}{66 \%}$ & $\frac{46.1 \mathrm{~g}}{58 \%}$ \\
\hline 2 & 93.8 & $\frac{78.5 \mathrm{~g}}{84 \%}$ & $\frac{72.0 \mathrm{~g}}{77 \%}$ & $\frac{65.9 \mathrm{~g}}{71 \%}$ & $\frac{60.5 \mathrm{~g}}{65 \%}$ & $\frac{55.9}{60 \%} \mathrm{~g}$ \\
\hline 3 & 96.1 & $\frac{82.9 \mathrm{~g}}{87 \%}$ & $\frac{77.2 \mathrm{~g}}{81 \%}$ & $\frac{71.0 \mathrm{~g}}{74 \%}$ & $\frac{64.8 \mathrm{~g}}{68 \%}$ & $\frac{58.9 \mathrm{~g}}{61 \%}$ \\
\hline 4 & 100.2 & $\frac{95.6 \mathrm{~g}}{95 \%}$ & $\frac{89.9 \mathrm{~g}}{90 \%}$ & $\frac{84.2 \mathrm{~g}}{85 \%}$ & $\frac{78.1 \mathrm{~g}}{78 \%}$ & $\frac{72.7 \mathrm{~g}}{73 \%}$ \\
\hline 5 & 94.9 & $\frac{83.5 \mathrm{~g}}{81 \%}$ & $\frac{74.9 \mathrm{~g}}{79 \%}$ & $\frac{65.6 \mathrm{~g}}{68 \%}$ & $\frac{58.0 \mathrm{~g}}{61 \%}$ & $\frac{50.8 \mathrm{~g}}{54 \%}$ \\
\hline 7 & 80.9 & 82.1 & 82.3 & 81.0 & 83.6 & 82.2 \\
\hline 8 & 93.5 & 92.6 & 92.3 & 91.2 & 93.2 & 91.9 \\
\hline 9 & 98.8 & 101.1 & 98.1 & 99.5 & 98.3 & 102.3 \\
\hline
\end{tabular}


TABLE VI

COMPARISON OF MEAN BODY WEIGHTS OF $5 \underline{E}$. T. TOWNSENDII

DEPRIVED OF DRINKING WATER AND 3 CONTROL ANTMALS

WITH AD LIBITUM ACCESS TO WATER

(EXPERIMENT I)

Days

Means of Weights of

5 Experimental Animals (g)
Means of Weights of

3 Control Animals (g)
0

1

2

3

4

5
93.0

81.8

75.4

68.8

62.7

56.6
85.3

83.2

86.2

86.4

88.6

87.9 
TABLE VII

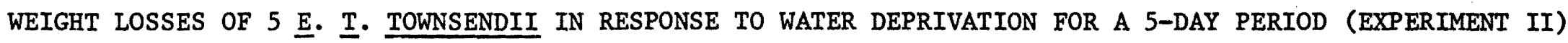
As compared to weight changes of 3 control animals ( 7,8 , and 9)

Upper figure is body weight; lower figure is per cent of pre-experimental weight

\begin{tabular}{|c|c|c|c|c|c|c|}
\hline $\begin{array}{l}\text { Animal } \\
\text { No. }\end{array}$ & $\begin{array}{c}\text { Pre-experiment } \\
\text { Weight }\end{array}$ & Day 1 & Day 2 & Day 3 & Day 4 & Day 5 \\
\hline 1 & 75.3 & $\frac{66.6 \mathrm{~g}}{89 \%}$ & $\frac{60.8 \mathrm{~g}}{81 \%}$ & $\frac{53.98}{72 \%}$ & $\frac{48.1 \mathrm{~g}}{64 \%}$ & $\frac{45.0 \mathrm{~g}}{60 \%}$ \\
\hline 2 & 91.5 & $\frac{78.3 \mathrm{~g}}{86 \%}$ & $\frac{71.0 \mathrm{~g}}{82 \%}$ & $\frac{64.4 \mathrm{~g}}{71 \%}$ & $\frac{59.6 \mathrm{~g}}{66 \%}$ & $\frac{56.6 \mathrm{~g}}{62 \%}$ \\
\hline 3 & 98.5 & $\frac{88.2 g}{90 \%}$ & $\frac{82.1 \mathrm{~g}}{84 \%}$ & $\frac{77.1 \mathrm{~g}}{79 \%}$ & $\frac{71.1 \mathrm{~g}}{73 \%}$ & $\frac{66.5 \mathrm{~g}}{68 \%}$ \\
\hline 4 & 111.5 & $\frac{102.0 \mathrm{~g}}{92 \%}$ & $\frac{94.1 g}{85 \%}$ & $\frac{88.2 g}{80 \%}$ & $\frac{82.9 \mathrm{~g}}{75 \%}$ & $\frac{79.1 \mathrm{~g}}{71 \%}$ \\
\hline 5 & 98.6 & $\frac{86.9 \mathrm{~g}}{84 \%}$ & $\frac{80.0 \mathrm{~g}}{82 \%}$ & $\frac{74.0 \mathrm{~g}}{76 \%}$ & $\frac{67.2 \mathrm{~g}}{69 \%}$ & $\frac{62.5 \mathrm{~g}}{64 \%}$ \\
\hline 7 & 74.6 & 72.6 & 78.9 & 78.7 & 80.0 & 81.9 \\
\hline 8 & 94.5 & 91.8 & 95.0 & 96.9 & 94.4 & 99.4 \\
\hline 9 & 89.5 & 87.6 & 91.8 & 89.9 & 91.5 & 94.6 \\
\hline
\end{tabular}


Control animals

Experimental animals

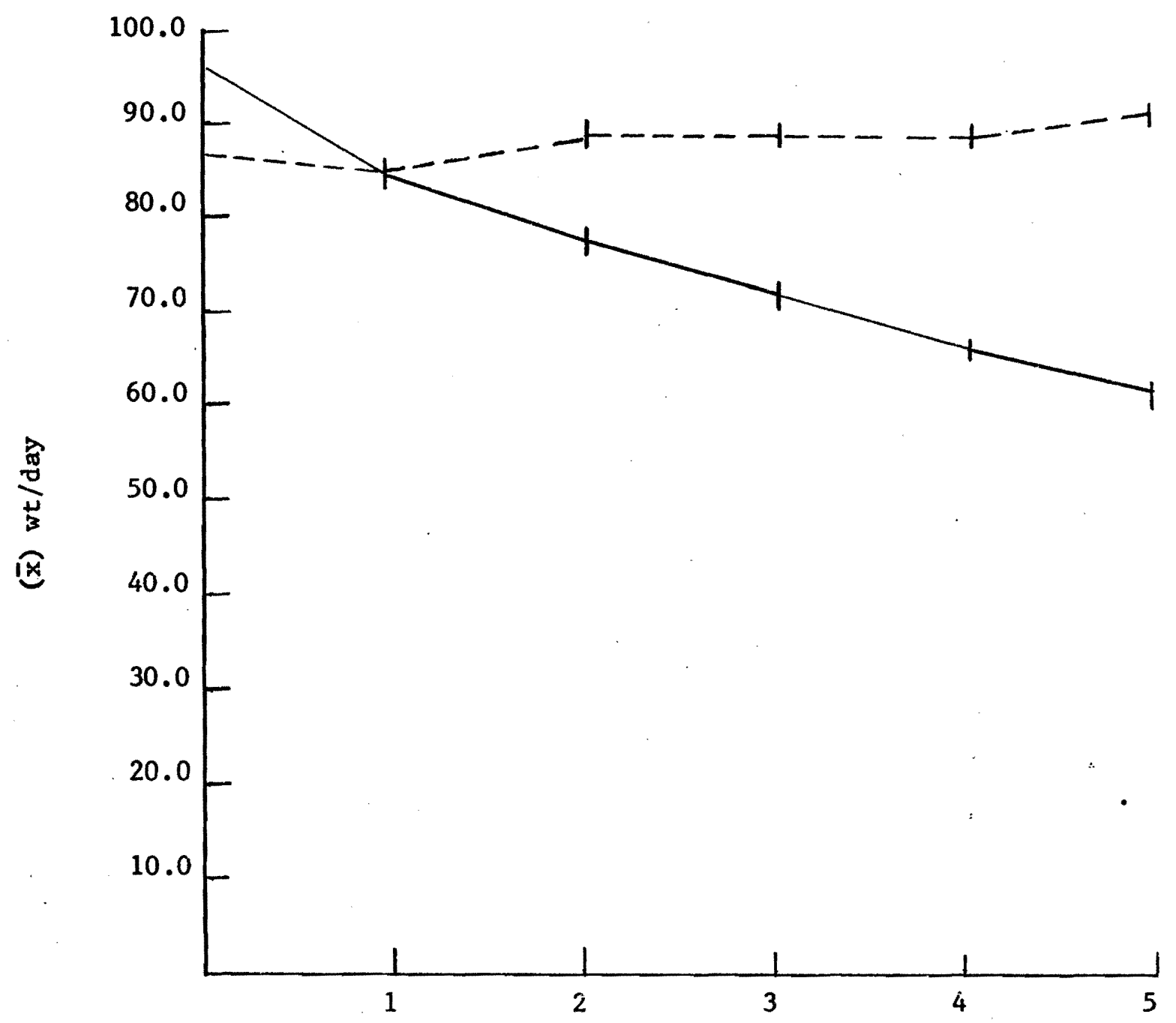

Days of Dehydration

Figure 1. Comparison of daily weight changes of 5 water-deprived and 3 contro1 E. t. townsendii (Experiment II). 
TABLE VIII

COMPARISON OF MEAN BODY WEIGHTS OF 5 E. T. TOWNSENDII DEPRIVED

OF DRINKING WATER AND CONTROL ANIMALS WITH

AD LIBITUM ACCESS TO WATER

(EXPERIMENT II)

$\begin{array}{ccc}\text { Days } & \begin{array}{c}\text { Means of weights of } \\ \text { 5experimental animals }(\mathrm{g})\end{array} & \begin{array}{c}\text { Means of weights of } \\ 3 \text { control animals }(\mathrm{g})\end{array} \\ 0 & 95.1 & 86.1 \\ 1 & 84.4 & 84.0 \\ 2 & 77.7 & 88.5 \\ 3 & 71.6 & 88.5 \\ 4 & 65.7 & 88.5 \\ 5 & 61.8 & 91.9\end{array}$


TABLE IX

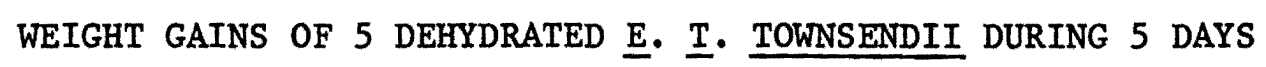

AFTER AD LIBITUM ACCESS TO DRINKING WATER WAS RESTORED

(EXPERIMENT I)

Upper figure is body weight in grams; lower figure is per cent of pre-experimental weight (See Table V).

\begin{tabular}{|c|c|c|c|c|c|c|}
\hline $\begin{array}{c}\text { Animal } \\
\text { No. }\end{array}$ & $\begin{array}{l}\text { Weight }(g) \text { after } \\
5 \text { days of } \\
\text { Water Deprivation }\end{array}$ & Day 1 & Day 2 & Day 3 & Day 4 & Day 5 \\
\hline 1 & $46.1 \mathrm{~g}$ & $\frac{58.9 \mathrm{~g}}{74 \%}$ & $\frac{64.9 \mathrm{~g}}{81 \%}$ & $\frac{67.7 \mathrm{~g}}{85 \%}$ & $\frac{68.0 \mathrm{~g}}{85 \%}$ & $\frac{67.4 \mathrm{~g}}{84 \%}$ \\
\hline 2 & $55.9 \mathrm{~g}$ & $\frac{63.3 \mathrm{~g}}{67 \%}$ & $\frac{58.4 \mathrm{~g}}{62 \%}$ & $\frac{54.9 \mathrm{~g}}{58 \%}$ & $\frac{57.7 \mathrm{~g}}{62 \%}$ & $\frac{63.3 \mathrm{~g}}{67 \%}$ \\
\hline 3 & $58.9 \mathrm{~g}$ & $\frac{66.4 \mathrm{~g}}{69 \%}$ & $\frac{65.9 \mathrm{~g}}{69 \%}$ & $\frac{70.7 \mathrm{~g}}{74 \%}$ & $\frac{74.6 \mathrm{~g}}{77 \%}$ & $\frac{76.3 \mathrm{~g}}{79 \%}$ \\
\hline 4 & 72.78 & $\frac{79.5 \mathrm{~g}}{79 \%}$ & $\frac{93.1 \mathrm{~g}}{93 \%}$ & $\frac{86.4}{86 \%}$ & $\frac{88.5 \mathrm{~g}}{88 \%}$ & $\frac{85.3 \mathrm{~g}}{85 \%}$ \\
\hline 5 & $50.8 \mathrm{~g}$ & $\frac{63.1 \mathrm{~g}}{66 \mathrm{c}}$ & $\frac{79.9 \mathrm{~g}}{84 \%}$ & $\frac{72.3 \mathrm{~g}}{76 \%}$ & $\frac{76.1 \mathrm{~g}}{80 \%}$ & $\frac{79.9 \mathrm{~g}}{84 \%}$ \\
\hline
\end{tabular}




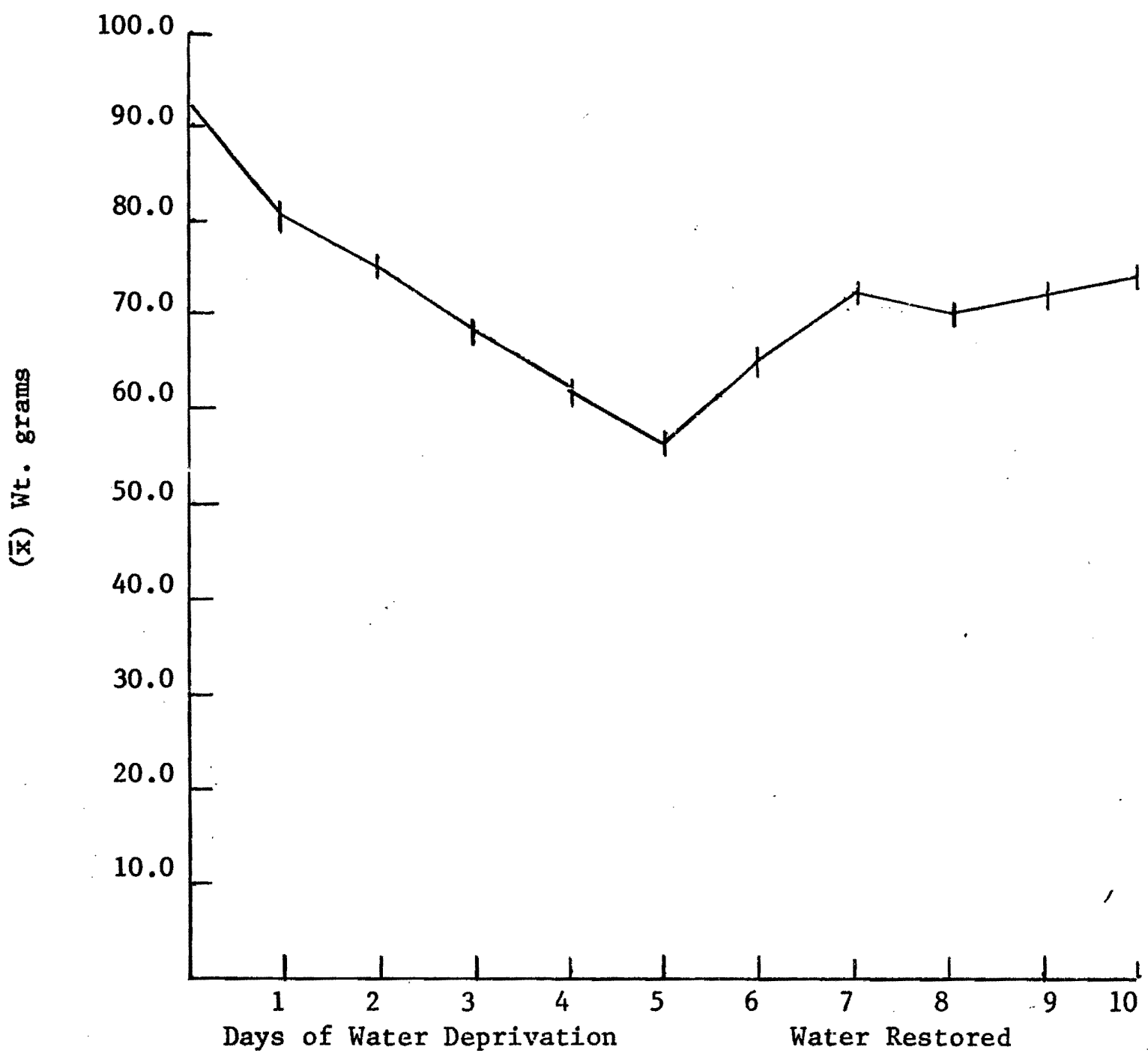

Figure 2. Mean daily body weights of $5 \mathrm{E}$. $t$. townsendii during water deprivation and when ad libitum access to water was restored (Experiment I). 
Salt water consumption

Weight changes and fluid consumption of five experimental animals in response to solutions of saline drinking water are shown in Tables $X-X I I$ and in Figures 3 and 4. When experimental animals were given saline solution Instead of tap water to drink, their fluid consumption Increased. Fluid consumption increased with the increase of molarity. Animals provided with $0.1 \mathrm{M} \mathrm{NaCl}$ solutions to drink maintained their normal body weight for the 5-day experimental period. Given $0.2 \mathrm{M} \mathrm{NaCl}$ solutions, the animals showed a body weight loss of only a few grams at the end of the 5-day experimental period. However, when the animals were given $0.4 \mathrm{M} \mathrm{NaCl}$ solution, they showed great and rapid losses of body weight. In only two days, three animals lost $13.5,10.2$ and 13.6 grams from their original weights. Two individuals died on the second day. At the time of death, these animals had lost 21.7 and 17.3 grams of their original weight. The experiment was terminated following the deaths of these two animals.

Fluid consumption, body weights and activity patterns of control animals did not change significantly during this experiment. 


\section{TABLE X}

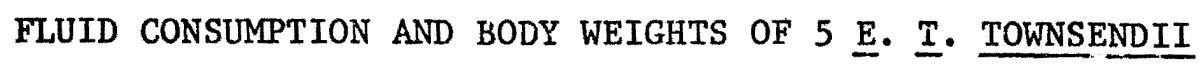

GIVEN $0.1 \mathrm{M} \mathrm{NaC1}$ SOLUTION TO DRINK

Day

Saline Solution Consumed per day (cc)

$(\bar{x}) / R$

$\underset{\bar{x} / R}{\text { Weight }}(g)$

1

$\frac{29.6}{18.0-43.0}$

$\frac{94.8}{87.1-101.8}$

2

$\frac{35.0}{17.0-51.0}$

$\frac{94.8}{86.7-101.2}$

3

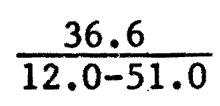

$\frac{93.0}{86.9-99.8}$

4

$\frac{41.1}{14.0-50.0}$

$\frac{93.4}{87.6-99.4}$

5

$\frac{32.6}{16.0-48.0}$

$\frac{94.5}{84.5-100.5}$ 


\section{TABLE XI}

FLUID CONSUMPTION AND BODY WEIGHTS OF 5 E. T. TOWNSENDII

GIVEN 0.2 M NaC1 SOLUTION TO DRINK

Day

1

2

3

4

5
Saline Solution Consumed
per day $(c c)$
$\bar{x} / R$

$\frac{40.4}{20.0-47.0}$

$\frac{41.0}{19.0-54.0}$

$\frac{40.4}{25.0-51.0}$

$\frac{36.4}{22.0-50.0}$

38.8

$\frac{38.8}{15.0-52.0}$
Weight (g)

$\bar{x} / \mathrm{R}$

$\frac{91.2}{81.5-99.1}$

$\frac{93.9}{82.4-104.5}$

$\frac{90.9}{81.2-96.3}$

87.5

$\frac{87.5}{72.2-95.8}$ 
TABLE XII

FLUID CONSUMPTION AND BODY WEIGHTS OF $5 \underline{\text { E. }} \underline{\mathrm{T}}$. TOWNSENDII

GIVEN 0.4 M SALINE SOLUTION TO DRINK

Day

1

2

3

$$
\begin{gathered}
\text { Saline Solution Consumed } \\
\text { per day }(c c) \\
\bar{x} / R
\end{gathered}
$$

$\frac{55.4}{52.0-58.0}$

$\frac{64.6}{48.0-77.9}$
Weight $(g)$ $\overline{\mathrm{x}} / \mathrm{R}$

$\frac{80.8}{70.1-90.7}$

$\frac{74.7}{60.5-82.0}$

* = Experiment terminated when two experimental animals died. 


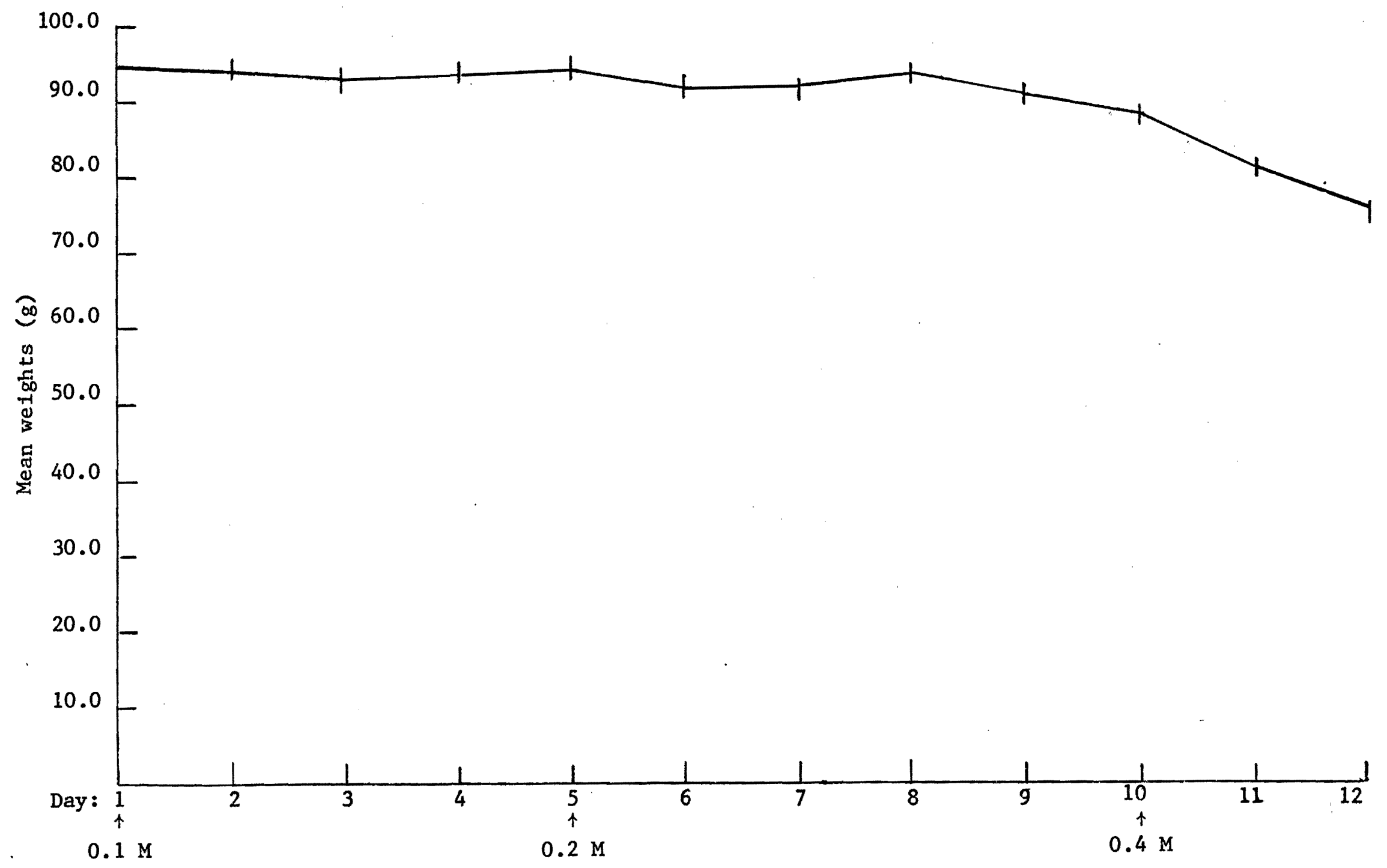

Figure 3. Mean daily body weight changes of $5 \underline{E}$. $\underline{t}$. townsendil given NaCl solutions to drink. $\tilde{\omega}$ 


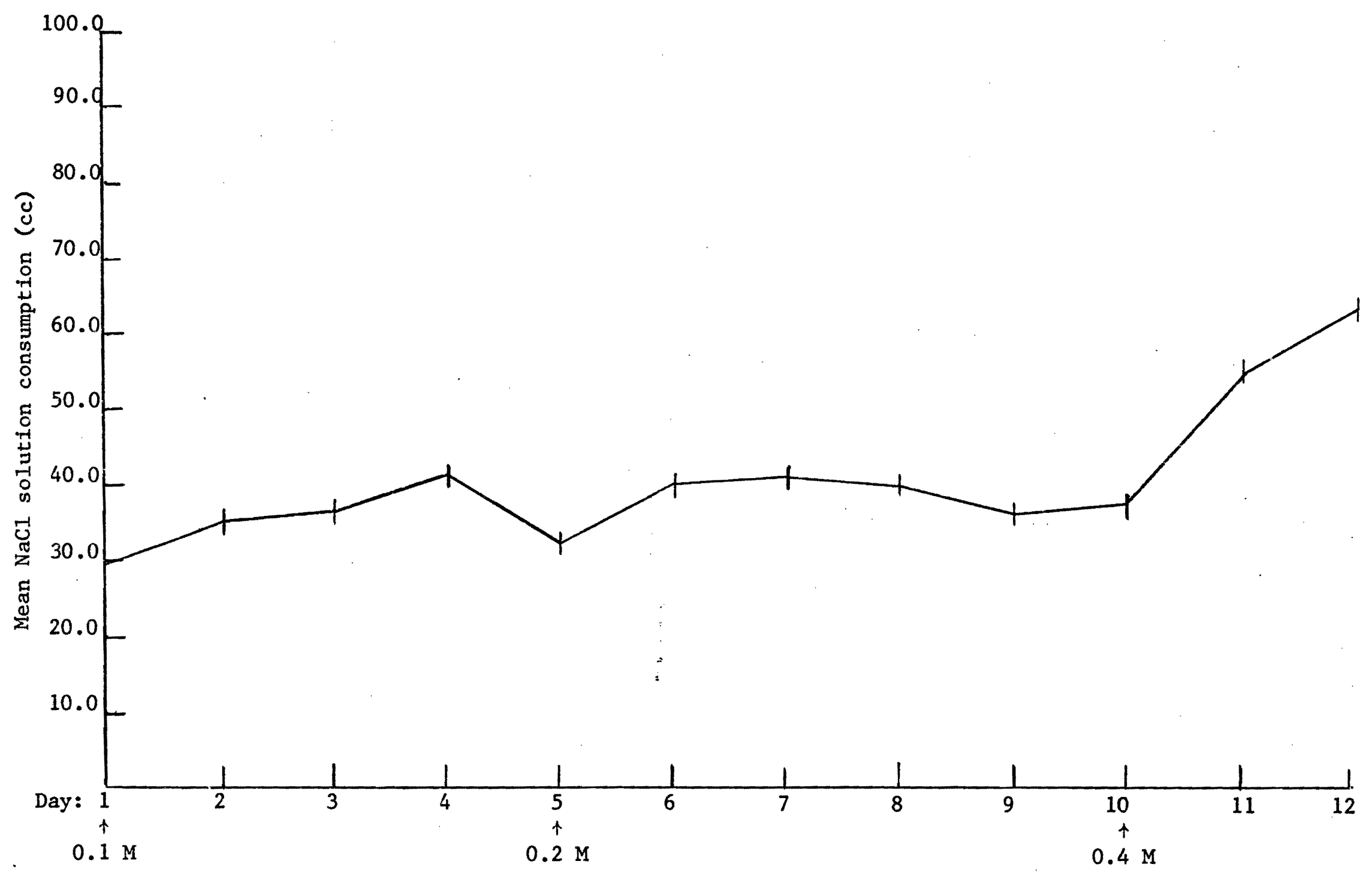

Figure 4. Mean daily consumption of NaC1 solutions by $5 \underline{E}$. … townsendil. 


\section{DISCUSSION}

\section{Ad libitum water consumption}

Because there have been so few studies of water economics of chipmunks, a comparison of my results with those of cthers must be limited. I know of no other physiological studies of $\underline{E} \cdot \underline{t}$. townsendii. The ad lib water consumption of my animals was 15.5 percent body weight/day for the first period and 23.5 percent body weight/day for the second period. The first value approximates Forbes' (1967) figures of 14 percent of body weight per day for $\underline{E}$. minimus and Tamias striatus. Wunder (1970) found that E. merriami, a desert species, consumed water amounting to 12 percent of body weight/day. Heller (1970) reported daily ad lib water consumption of 16 percent of body weight per day for captive $\underline{E}$ alpinus, $\underline{E}$. speciosus, and E. amoenus, and 11 percent for $\underline{E}$. minimus (a desert subspecies).

The higher value I obtained during the second period reflects greatly increased water consumption (compared to the first period) by a few animals (see Tables I and II). Increases in consumption by most animals were small. It is possible that during the second period animals such as $\# 1$ spilled water in quantities large enough to affect apparent consumption, but too small for me to detect during my daily checks. I think that the average daily ad lib water consumption for captive $\underline{E}$. $\underline{t}$. townsendii is in the range of 15-16 percent of body weight. This value is closely comparable to those obtained for most non-desert chipmunks so far studied.

The mean water consumption per gram of body weight per animal per 
day for my animals ranged from 0.08 to 0.20 in the first period and from 0.12 to 0.26 in the second period. The animals that drank more than the average amounts of water were more active than the others, judging from the disturbance of cage 1itter and from the animals' behavior when I checked them daily. The possibility that undetected water spillage affected some values has already been noted. However, Forbes (1967) and others have noted that variation in chipmunks' water consumption tends to be high, both for different individuals, and for a given individual at different times. Duration of time in captivity may affect an animal's water consumption. Bartholomew and Hudson (1956), found that freshly captured antelope ground squirrels (Ammospermophilus leucurus) averaged as much as $0.16 \mathrm{cc}$ per gram per day while fat animals that had been long in captivity averaged as 1ittle as $0.07 \mathrm{cc}$ per gram per day. Panuska and Wade found that the ad lib water consumption of Tamias striatus decreased from $33.4 \mathrm{cc}$ per day to $29.2 \mathrm{cc}$ after several weeks in captivity. Among my animals, the one which drank an average of $0.08 \mathrm{cc}$ of water per gram of body weight per day was the one given to me after it had been confined outdoors for about 8 months. The chipmunk which averaged $0.17 \mathrm{cc}$ per gram per day was freshly captured.

Panuska and Wade (1955) attributed the high daily water consumption (average $33.4 \mathrm{cc}$ ) of Wisconsin Tamias striatas to the fact that the chipmunks inhabited an area in which there are numerous small lakes that provide easy access to water. E. $\underline{\text { t. }}$ townsendii also occupies an area in which water is normally plentiful. This species may also be adapted to and dependent on a relatively plentiful supply of drinking water. 
Responses to water deprivation

The ability of rodents to maintain body weight at low water intake or when deprived of free water is generally related to a high waterconserving mechanism associated with arid situations (Abbott 1970). For example, Wunder (1970) found that although the desert-dwelling Eutamias merriami in captivity drank water equal to 12 percent of its body weight per day, that figure could be reduced to 1.5 percent when the animals were placed on water restriction, with body weights held constant at 23 percent less than when the animals were on an ad lib water regimen. If E. t. townsendii is in fact dependent on a regular and abundant supply of drinking water, one would not expect these animals to be able to maintain their weight when deprived of drinking water. The data in Tables V-VIII seem to confirm this hypothesis. Body weight losses of water-deprived animals were rapid and amounted to as much as a 46 percent weight loss in five days. However, since water-deprived animals were also found to stop eating their body weight loss during water deprivation is partially attributable to dehydration and partially to voluntary reduction in feeding. Wunder (1970) noted that if water loss per gram is constant, then an animal which reduces its body weight will show a reduced absolute. water loss per unit time. Restricting food intake may also reduce the need for water used to eliminate urea and salts. However, a starving chipmunk cannot be expected to show normal activity, especially if the animal is partially dehydrated as well. The changes in activity of some of my animals deprived of water would have been highly non-adaptive in the wild. These responses, the fact that body weights of my experimental animals did not level off, even after weight losses of up to 46 percent, 
and the death of two animals following the second period of water deprivation, further suggest to me that $\underline{E}$. $\underline{t}$. townsendil probably requires a dependable source of drinking water. However, water intake from eating moist vegetation may serve their needs, at least for a limited time. It seems possible that the water requirements and intolerance of Townsend's chipmunks for dehydration may be limiting factors in their habitat selection.

\section{Saline solution consumption}

The ability of a mammal to utilize concentrated saline solution is related to 1 ife in a habitat where most of the avallable free water and plants are relatively high in salinity (Abbott 1970). Some desert rodents, such as Notomys cervinus (MacMillen and Lee 1969) and Dipodomys merriami (Schmidt-Nielsen and Schmidt-Nielsen 1950) can maintain their body weights given water as salty as or saltier than sea water. In these desert rodents the ability to utilize concentrated saline solution appears to be related more to kidney efficiency in concentrating urine rather than to a physiological adaptation to natural salt water sources (Abbott 1970). The Mongolian gerbil (Meriones unguiculatus) can maintain normal body weights for 45 days given $0.8 \mathrm{M} \mathrm{NaCl}$ (Winkelmann and Getz 1962). Haines (1964), Fisler (1962, 1963), and Bartholomew and Hudson (1956) have shown that several North American smali rodents can drink sea water or even saltier water and derive a net water gain. Since part of the range of $\underline{E}$. t. townsendii includes Pacific coastal regions where the salty water of tide pools, estuaries, or sea spray are available to drink, it is appropriate to wonder if townsendii could use these water sources and survive. 
The weight stability of experimental chipmunks drinking $0.1 \mathrm{M}$ and $0.2 \mathrm{M} \mathrm{NaCl}$ solution (Tables X-XII) indicates that the animals were able to obtain a sufficient net gain of water to satisfy their metabolic needs. However, when the animals were given $0.4 \mathrm{M}$ saline solution, they consumed more salt solution than before, yet they lost weight very quickly and after only two days on this regimen two of the five experimental animals died. It is possible that the stress of drinking $0.4 \mathrm{M} \mathrm{NaCl}$ solution was increased by having consumed the $0.1 \mathrm{M}$ and $0.2 \mathrm{M} \mathrm{NaCl}$ solutions earlier. However, no data were gathered to test that hypothesis. Death of the. animals on salt solutions should be principally due to a toxic effect of the salt rather than to dehydration (Fertig and Layne 1963). This seems to be true among my animals. In the water deprivation studies, two animals lost 34 percent and 34 percent of the original weights and recovered their normal weights given ad lib access to water. The animals that died when given $0.4 \mathrm{M} \mathrm{NaCl}$ had lost only 19 percent and 29 percent of their original weights. Some animals, perhaps because they drank less $0.4 \mathrm{M} \mathrm{NaCl}$ solution and thus took in less salt, were able to survive 1onger.

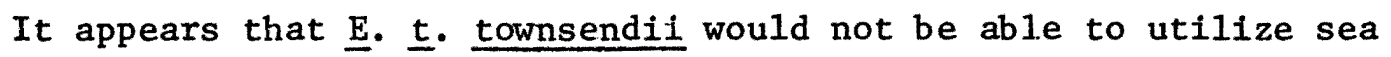
water for a source of drinking water. However, if sea water were sufficiently diluted (to $0.2 \mathrm{M}$ or less) by rain or dew, the resulting solution would seemingly be useful to coastal chipmunks for drinking purposes. 


\section{SUMMARY AND CONCLUSIONS}

Results of these investigations suggest that $\underline{E} . \underline{t}$. townsendii is dependent on a source of drinking water if normal body weight and activity are to be maintained. Water deprivation results in rapid body weight loss through dehydration and through voluntary fasting. Such weight losses may represent defense of water balance. However, some individuals die after five days of water deprivation. These chipmunks are unable to use $0.4 \mathrm{M} \mathrm{NaCl}$ solutions for drinking and survive for more than a few days. Saline solutions of $0.1 \mathrm{M}$ and $0.2 \mathrm{M}$ can be consumed with no significant change in body weight. Thus, while sea water would usually be an unacceptable source of drinking water for coastal chipmunks, a dilute solution of salt water could be used, at least for a short time. 
REFERENCES CITED

Abbott, K. 1970. Water economy of the canyon mouse, Peromyscus crinitus stephensi. Comp. Biochem. Physiol. 38: 37-5:.

Bailey, V. 1936. The mammals and life zones of Oregon. N. Amer. Fauna. 55: $1-416$.

Bartholomew, G. A. and J. W. Hudson. 1956. Effect of sodium chloride on weight and drinking in the antelope ground squirrel. J. Mamm. 40: $354-360$.

Fertig, D. S. and J. N. Layne. 1963. Water relationships in the Florida mouse. J. Mamm. 44: 322-334.

Fisler, G. F. 1962. Ingestion of sea water by Peromyscus maniculatus. J. Mamm. 43: 416-417.

- 1963. Effect of salt water on food and water consumption and weight of harvest mice. Ecology 44: 604-608.

Forbes, R. B. 1967. Some aspects of the water economics of two species of chipmunks. J. Mamm. 48: 466-468.

Haines, H. 1964. Salt tolerance and water requirements in the saltmarsh harvest mouse. Physiol. Zoo1. 37: 266-272.

Heller, H. C. 1970. Altitudinal zonation of chipmunks (Eutamias): interspecific aggression, water balance, and energy budgets. $\mathrm{Ph} . \mathrm{D}$. thesis, Corne11 University.

Jameson, E. W., Jr. and R. A. Mead. 1964. Seasonal changes in body fat, water and basic weight in Citellus lateralis, Eutamias speciosus and E. amoenus. J. Mamm. 45: 359-364.

MacMillen, R. E. and A. K. Lee. 1969. Water metabolism of Australian hopping mice. Comp. Biochem. Physiol. 28: 493-514.

Panuska, J. A. and N. J. Wade. 1957. Field observation on Tamias striatus in Wisconsin. J. Mamm. 38: 102-196.

Schmidt-Nielsen, Bodil and K. Schmidt-Nielsen. 1950. "Do kangaroo rats thrive when drinking sea water?" Amer. J. Physiol. 160: 291-294.

Simpson, G. G., Anne Roe, and R. C. Lewontin. 1960. Quantitative zoology, revised edition. Harcourt, Brace and Co., New York 
Winkelmann, J. R. and L. L. Getz. 1962. Water balance in the Mongolian gerbil. J. Mamm. 43: 150-154.

Wunder, B. A. 1970. Temperature regulation and the effects of water restriction on Merriam's chipmunk, Eutamias murriami. Comp. Biochem. Physiol. 33: 385-403. 